\title{
On the relation between (verbal and kinesic) downtoning and illocution type
}

\author{
Steven Schoonjans \\ Leopold-Franzens-Universität Innsbruck and KU Leuven/FWO-Vlaanderen \\ steven.schoonjans@uibk.ac.at
}

\begin{abstract}
"Downtoning" can be understood as the nuancing of an utterance in view of the interlocutor's reaction. Typical downtoners in German include the so-called modal particles, although downtoning can also be expressed in other ways, including at the non-verbal level by means of gestures. Given their meanings, downtoning elements are typically restricted to particular illocution types. The goal of this paper is to investigate how this link between downtoning and illocution type is reflected in the use of these downtoners. This is done for both verbal and gestural downtoners in German and for downtoning patterns in German Sign Language (DGS). The question is addressed from two points of view, looking first at the topology of the downtoners in German and DGS, then at the kind of gestural markers co-occurring with verbal downtoners in German.
\end{abstract}

Keywords: downtoning; illocution type; modal particles; gesture; sign language.

\section{Downtoning and illocution type: Setting the scene}

\subsection{Introduction}

Language users have different techniques at their disposal to express their stance and add nuances to their utterances. One of these is called "downtoning" (from German Abtönung). In line with Waltereit (2006: 62), "downtoning" can be understood as the modification of an utterance in view of the expected reaction by the hearer: the speaker adds an (inter)subjective nuance, expressing, for instance, his take on the utterance or on how it relates to the context, while at the same time trying to steer the way the interlocutor reacts or giving an indication of how (s)he is expected to react. ${ }^{1}$

\footnotetext{
${ }^{1}$ Note that, unlike what the term "downtoning" may suggest, it is not restricted to downplaying, softening, or weakening: As the examples discussed in the following will show, it also encompasses certain cases of intensification or illocutive strengthening.
} 
This can be illustrated nicely by means of the most typical verbal downtoners in German, the so-called "modal particles" or "downtoning particles" (Modalpartikeln or Abtönungspartikeln in German). By using etwa in a yes/noquestion (1a), for instance, the speaker indicates that the situation described is undesirable (speaker's take) and that therefore, a negative answer is preferred (expected hearer reaction). Similarly, halt in (1b) indicates that the situation described is obvious and cannot be changed (speaker's take) and that therefore any discussion about it is pointless (hearer's reaction). (For lack of direct English counterparts, the translations of the particles can only be approximations giving an indication of their meanings.)

(1a) Hast du etwa wieder den Polizeifunk abgehört? (COSMAS-II) 'Have you been monitoring the police radio again? I hope not...'

(1b) Eine zukunftsorientierte Zeitung ist halt nicht nur ein Medium ex cathedra. (COSMAS-II)

'A future-oriented newspaper simply is not just an ex-cathedra medium.'

The aim of this paper is to investigate how the expression of downtoning interacts with illocution type marking. This will be done not just for German modal particles (\$1.2), but also for gestures related to downtoning in German and for downtoning structures in German Sign Language (DGS) (\$1.3).

\subsection{Downtoning at the verbal level: German modal particles}

In total, German has some 15 to 20 modal particles, expressing different nuances (for a more encompassing overview of the category: see e.g. Thurmair 1989; and Müller 2014). For the remainder of this paper, nine of them are of particular interest - next to etwa and halt also the particles denn, ja, doch, eben, einfach, $n u r$, and $b l o \beta$, as illustrated in (2).

(2a) Ich bin froh, dass der Januar vorbei ist. - Echt? Warum denn?

(FG_B1b)

'I'm happy that January is over. - Really? But why?' 
(2b) Es sind die Bürger insofern gestärkt, weil ja jedes Dokument jetzt frei im Internet abrufbar ist. (PR_Schü0811)

'The position of the citizens has been strengthened to the extent that, as you know, each document is now freely available through the internet.'

(2c) Ich lach mich doch schief, wenn mir jemand erklären will, dass Abgeordneter Pilz wirklich untersuchen wollte. Dem war doch völlig Wurst, was zu untersuchen war! (PR_West2911)

'I can't help laughing when someone tries to tell me that Deputy Pilz really wanted to investigate. As you know, he couldn't care less about what was to be investigated!'

(2d) Die EU wird handlungsfähiger [...] wenn auch aufgrund der polnischen Interventionen erst in zehn Jahren, aber so ist eben europäische Politik, dass es manchmal sehr lange dauert. (PR_VDB0811)

'The EU becomes more capable of acting [...] albeit only in ten years because of the Polish interventions, but that's just the way things go in European politics, it sometimes takes quite some time.'

(2e) Wir wollen die Neutralität weiterhin bewahrt wissen; das ist uns einfach ein wichtiges Thema. (FG_Strac3010)

'We want to stay neutral; that simply is an important thing to us.'

(2f) Wie ist das nur möglich? (COSMAS II)

'But how is that possible?'

(2g) Warum zögere ich blo $\beta$ immer so lange? (COSMAS II)

'But why do I always hesitate so long?'

The function of denn (2a) is to indicate that the speaker asks the question because of something astonishing or unexpected in the speech situation. Typically, this source of astonishment is the previous utterance, as in (2a), where the speaker had not expected the interlocutor to be happy that January is over. The particles $j a$ and doch both indicate that the speaker thinks that the content of the utterance is actually part of the common ground, i.e. that the hearer already knows it, or at least that the speaker does not expect the hearer to contradict it. Hence, in (2b), which stems from a parliamentary speech, everyone in the audience is expected to know that all documents are freely available. The main dif- 
ference between $j a$ and doch is that the latter particle also expresses a kind of adversativity, in that there seems to be a contradiction between what is said (hence: what the hearer should know) and what the hearer is assuming or doing, usually implying that these assumptions or actions should be modified in such a way as to be compatible with the common ground information. In the case of (2c) this can be formulated as 'you seem to be convinced that he wanted to investigate, although you know that he could not care less'.

The particles eben and einfach are closely related to halt in that they also mark the content of the utterance as obvious, unchangeable, or the only possibility: unless you have extraordinary power, you cannot change the way things go in international politics (2d), and in (2e), the speaker indicates that the neutrality of the country is not a matter of discussion. $N u r$ and $b l o \beta(2 \mathrm{f}-\mathrm{g})$, finally, can be used in different sentence types, but the most relevant for this paper is their use in $w h$-questions. In this context, they mark "particular subjective interest from the side of the speaker" to get to know the answer (Thurmair 1989: 179; my translation), often implying that the speaker actually has no idea of what the answer could be.

\subsection{Downtoning at the kinesic level}

While modal particles are often considered as the German downtoners "par excellence", they are not the only elements that can convey downtoning meanings. Apart from other verbal and paraverbal markers such as question tags and particular intonation patterns (see Heinrichs 1981: 66-86 for an overview), the nonverbal layers of communication (gesture, posture, and the like) also contribute to the expression of downtoning (see also Schoonjans 2014 for a more encompassing overview of the gestures at issue).

The gestures involved in downtoning can be both manual and non-manual. An example of a manual downtoning gesture is the so-called interpersonal deictic, a (usually flat-hand) pointing gesture directed at the interlocutor and used to mark (among other things) shared knowledge or agreement (similarly to $j a$ ). Another example is the gesture Kendon (2004: 275) refers to as "Open Hand Supine with lateral movement", i.e. a palm-up open hand gesture moved to the side (and sometimes slightly backwards) and used as a sign of "nonintervention" (Kendon ibidem) or withdrawal. As Kendon himself indicated, this gesture can be used as a marker of obviousness and thus relates to particles such as halt. Similarly, the corresponding gesture with the palm facing down- 
wards (Kendon's [2004: 255] “Open Hand Prone ZP gestures”, called "sweeping away" by Bressem and Müller 2014: 1596) can be used, among other things, to "exclude all other possibilities" (Kendon 2004: 258), which also relates it to particles such as eben and halt.

While these manual gestures will be included in the counts in Section 4, the focus in the remainder of this paper will be on the non-manuals. These include gestures such as head nodding, headshakes, head tilts, and shoulder shrugs. Each of these gestures can be used in different contexts and with different functions, some of which can indeed be related to downtoning meanings as expressed by modal particles. The headshake, for instance, is traditionally seen as an emblem of negation, for instance as (part of) a negative answer. Apart from that, it can also express "implicit negation" (Kendon 2002), rejecting any alternatives or counterarguments, which relates it to the obviousness meaning of einfach, or indicate with questions that the speaker has no idea of what the answer could be (cf. nur and bloß). Similarly, head nodding is not just used as a positive answer or as a backchannel, but also during an utterance to indicate that the speaker himself stands to his utterance and does not expect contradiction (cf. the modal particle $j a$ ), or during a question to project an affirmative answer (cf. Whitehead 2011: 113). As for the shoulder shrug, Debras and Cienki (2012: 936) have shown that it is not just a sign of ignorance but also a marker of obviousness, and for the lateral head tilt, Mangelschots and Schoonjans (2017) have indicated that it can also be used to signal obviousness, similarly to the headshake and the shrug.

One of the reasons for focusing on non-manuals in the following is that they also constitute the main means of downtoning in DGS. Indeed, in DGS, the situation is different from German in that DGS does not have fixed, conventionalized lexical signs to mark downtoning: "German modal particles do not have DGS sign equivalents" (Herrmann 2007: 269). Downtoning meanings in DGS are mainly expressed by non-manual markers, which include facial expressions, but also markers corresponding to or at least closely resembling the gestures described above for spoken language. DGS also makes use of headshakes and shoulder shrugs in contexts of obviousness and head nodding is used to show that signers stand to their utterances, to mention just three examples (see Herrmann 2013 for a more extensive overview). While a detailed comparison of these markers in German and DGS goes beyond the scope of this paper, it will be shown in the following that they do at least behave in a similar way when it comes to their interaction with illocution type marking. 


\subsection{Research question: Downtoning and illocution type}

A typical feature of downtoning elements is that they can only be used in particular illocution types (so far, this has only been claimed explicitly for modal particles, but it also holds for kinesic downtoners). An important reason is meaning: not every downtoning nuance is compatible with just any illocution type. A case in point is the common-ground-marking particle $j a$, which cannot be used in yes/no-questions, because you do not normally question information while at the same time marking it as shared knowledge. In this respect, downtoning elements can be seen as indications of the illocution type: If a particular downtoner is used, this is a sign that we are dealing with an illocution type in which it can occur.

Hence, we can say that there is a link between downtoning and illocution type. The precise nature of this link is, however, still a matter of discussion. Scholars disagree, for instance, on whether downtoners simply indicate the illocution type or whether they also modify it (see e.g. Autenrieth 2002: 24-26). While resolving this issue is beyond the scope of this contribution, the main objective in the following is to investigate how the link between downtoning and illocution type is reflected in the use of both verbal and kinesic downtoners in German and DGS.

The question will be discussed from two different angles, related to topology and formal typology. In Section 3, I will show how the topology of both verbal and kinesic downtoners in German and DGS relates to the presence of illocution type markers, while in Section 4, I will turn to the idea that modal particles can develop into illocution type markers and discuss how the types of gestures co-occurring with the particles shed new light on this matter. Before commencing this discussion, however, some methodological remarks are called for (Section 2).

\section{Data and transcriptions}

To a large extent, the discussion in the following is based on observations that have been made in the literature before, especially for the verbal markers, although at the kinesic level, it is also underpinned by a further analysis of the data used for existing descriptions of gestural downtoning in German (Schoonjans 2014) and downtoning in DGS (Herrmann 2013). For German, this is the corpus Fernsehgespräche ('television conversations'), consisting of c. 17 hours of tele- 
vised interactions, mainly from talk shows and sports reports. The DGS dataset going with Herrmann (2013), on the other hand, consists of elicited materials, mainly elicited sentences and retellings of short stories. (Further details on the respective datasets can be found with Schoonjans 2014: 129-135 and Herrmann 2013: 62-71.) Hence, the data used for this study do not represent the most spontaneous type of interaction (especially in the case of DGS), and furthermore, they are not fully comparable. Nevertheless, these data allow for some interesting observations, which will be presented in the following.

Transcription conventions in sign linguistics and spoken language studies are traditionally rather different. For the sake of consistency, a symbiotic system will be used throughout this paper, uniting elements from both traditions. Sign language is mostly transcribed using glosses in small caps; non-manuals are indicated above these glosses, with a horizontal line indicating their spreading, as in (3a), where the nodding (hn) only accompanies the sign NUR 'only' (see Herrmann 2013: xvii-xviii and 353-357 for an overview of the relevant markings in the context of downtoning). As the use of glosses is uncommon for the study of spoken languages, the verbal layer of the spoken data is transcribed following the more common GAT2 conventions (Selting et al. 2009), but the gestures will be indicated in the same way as the non-manuals in the signed data, as shown in (3), which would be the German counterpart of (3a).

\begin{tabular}{|c|c|c|c|}
\hline & $\mathrm{hn}$ & & \\
\hline TIM IX-3 & $\overline{\text { NUR }}$ & BLUME & GIESS \\
\hline TIM IX-3 & ONLY & FLOWER & WATER $^{2}$ \\
\hline
\end{tabular}

$$
\text { tIm hat } \frac{h n}{\text { nur }} \text { die BLUmen gegossen. }
$$

\section{Topology}

The first part of the discussion concerns the topology of the downtoners, i.e. at which point in the sentence they occur in the case of verbal markers, or which elements they "spread over" (i.e. co-occur with) in the case of kinesic markers.

\footnotetext{
${ }^{2}$ IX-3 is a third person indexical/deictic, referring in this case to Tim. Further examples also include the gloss 'g-pu', which stands for the so-called palm-up. For the sake of readability, other non-manuals than the ones at issue will be left out from the transcripts.
} 
Two kinds of illocutions will be discussed in more detail in the following: partial interrogatives (3.1) and assertives (3.2).

\subsection{Partial interrogatives}

Partial interrogatives are questions that ask for a particular information. Typical$1 y$, the requested information is specified by means of a wh element (a question word or question sign), although this is not by definition the case. A police officer can for instance just ask Name?, meaning 'What is your name?', and similarly, in DGS, this question can be restricted to POSS-2 NAME ('your name') (or even just NAME without the possessive) accompanied by the non-manual marking for partial questions, without the question sign WAS ('what'). However, the distribution of downtoners is not just determined by the illocution type, but also by the sentence type (Thurmair 1993). Therefore, the following discussion will be restricted to $w h$-questions (i.e. partial interrogatives containing a question word/sign) for the sake of comparability, partial interrogatives without wh element being clearly less frequent in the German data than in the DGS data.

Strikingly, the German data do not contain any variation when it comes to the topology of downtoning gestures with $w h$-questions: they always cover the entire clause. This can be illustrated nicely by means of the headshake. This gesture is typically interpreted as a negating element, but it can also indicate, with partial questions, that the speaker is surprised and has no idea whatsoever of what the answer could be. In this respect, it resembles a modal particle combination such as denn blo $\beta$, where denn indicates that the question is raised following some surprising element in the speech situation (typically in the preceding utterance), while blo $\beta$ marks a "particular subjective interest from the side of the speaker" (Thurmair 1989: 179; my translation), a nuance that can be ascribed to the headshake as well. The following example illustrates this use of the headshake. In this example, the comedian Mike Krüger is telling about his wife going to the bank and being astonished hearing that the employee thought she was in Australia. Krüger enacts his wife's surprise, not knowing why the employee thought that, by means of a headshake.

$$
\text { (FG_B1a:543-548) }
$$

und zwAr kam meine frau montags in die BANK morgens, am SCHALter- 
und da sagte ich dEnke sie sind nach ausTRAlien frau krüger;

sagt meine frau $\frac{h s}{\text { WIE- }}$

wie w wie kOmmen sie DArauf?

'Indeed, my wife came into the bank on Monday morning, at the counter, and there [the employee] said: "I thought you were in Australia, Mrs Krüger." My wife asks: "What?

What w what makes you think that?",

From a comparative point of view, the fact that the gesture always extends over the entire clause is perhaps not the most interesting observation. What is more relevant in view of the comparison with DGS is that, as it extends over the entire clause, the gesture always also co-occurs with the question word. This is interesting, given that in the DGS data used for this study, downtoning nonmanuals in $w h$-questions always cover the last realization of the question sign. The exact spreading of the marker may vary, which is due among other things to the fact that the positioning of $w h$ elements in DGS is more variable than, for instance, in German, including the possibility of repeating a clause-initial question sign at the end, but at least the last realization of the question sign is always covered by the downtoning non-manual. Examples (5a-b) stem from the retelling of the same story by different informants. They are enacting Emma's reaction after being told that Tim, who is never ill, has to go to the hospital, and while the extension of the headshake (one again indicating that the speaker is surprised and has no clue) is different, it in both cases covers the question sign.

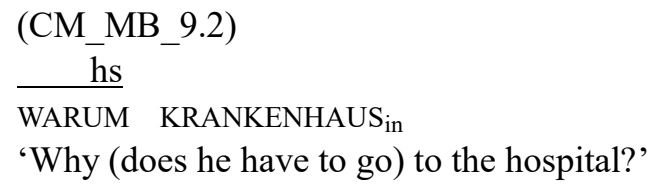

(5b) (JE_MB_9.2b)

hs

STIMMT WARUM KRANKENHAUS in $_{\text {g-pu }}$

'Really? Why (does he have to go) to the hospital?' 
This tendency to cover at least (the last realization of) the question sign is reminiscent of the topology of modal particles in German. It is a typical feature of German modal particles that they normally occur in the so-called middle field of the sentence, i.e. between the finite and the infinite verb, but one major exception concerns $w h$-questions, in which they can also occur immediately after the question word in the front field, as in (6a-b) (see e.g. Thurmair 1989; OrmeliusSandblom 1997; Abraham 2010 and Schoonjans 2015).

(6a) Warum, warum nur ist immer alles so furchtbar für mich? (F. Zorn, Mars, p.160)

'Why, o why is everything always so dreadful to me?'

(6b) Was eigentlich macht ein Bundestagsabgeordneter in Berlin? (COSMAS-II)

'What actually is a Member of the Bundestag doing in Berlin?'

This admittedly does not occur all that often: according to Schoonjans (2015: 426 ), only $2.23 \%$ of modal particles in $w h$-questions take this position (note that this count is based on purely written data; in spontaneous speech, the percentage may be somewhat higher). Nevertheless, it is striking that the downtoners here leave their normal middle-field position to join the wh elements, i.e. precisely those elements which in the DGS data are always accompanied by the downtoners. So far, two explanations (that need not be mutually exclusive) have been put forward for this "deviant" position of modal particles. On the one hand, Trotzke and colleagues (Bayer and Trotzke 2015; Trotzke and Turco 2015) interpret it as a form of "emphasis for intensity", while on the other hand, Thurmair (1989) and Brandt et al. (1992) refer to the aforementioned link between modal particles and the illocution type: because they are related to the illocution type, modal particles join other elements that explicitly indicate the illocution type (in this case, the question word). While the data under investigation do not allow to draw any conclusions on the former theory, the topology of the kinesic markers seems to offer support for the latter. Indeed, the kinesic marking always accompanies the $w h$ element, so this is its basic behavior and not an emphatic variant, but still it is striking that it is precisely the illocution-type-marking $w h$ element that is at stake both for German particles and for DGS downtoners. 


\subsection{Assertives}

Further support for the idea that the topology of downtoners is influenced by the presence or absence of explicit illocution type marking can be found at different levels. One is the topology of modal particles in another clause type with explicit illocution type marking, viz. (in)subordinates, as in (7a-b). These cases are harder to interpret, as it cannot be excluded that the particles are actually occurring in their basic middle field position, yet Schoonjans (2016) has suggested that we can assume a kind of attraction between the (illocution-type-marking) subordinator and the modal particle, similar to the attraction between question words and modal particles. To what extent this is reflected in the topology of downtoning gestures in a similar way as what we found for the partial interrogatives still remains to be investigated, however.

(7a) Das müssen sie sein, weil ja der Winter beziehungsweise der Tod noch vertrieben werden soll. (Schoonjans 2016: 80)

'They have to be like that, because winter, or rather death, still has to be cast out.'

(7b) Wenn nur die anderen nicht so engstirnig wären! (COSMAS-II)

'If only the others were not so narrow-minded!'

Another source of evidence is the topology of downtoners with assertions. As the default illocution type, assertions typically do not contain any elements that can be considered as explicitly marking the illocution type (intonation and word order are not considered as explicit markers here). Interestingly, assertions present the only illocution type in both German and DGS in which kinesic downtoners can occur in an incremental position, meaning that they do not co-occur with any lexical elements of the sentence, but rather appear immediately after its projected termination point, as in the following examples. The relevant gesture this time is a head nodding of affirmation, similar to the German particle $j a$. As indicated in section 1 , the function of $j a$ is typically described as indicating that the information is actually shared knowledge, but as Rinas (2007a) has shown, it can also indicate that the speaker considers the utterance as true and does not expect the hearer to contradict. This is also what the incremental nodding in (8a-b) expresses: it is true (according to the speaker) that she only learned to ski when she was $42(8 a)$ and that he sold his car (8b). 
(8a) (FG_B1b:33-39)

IN sind sie denn AUch ne SCHIfahrerin?
oder-
HL ja
ich hab das erst gelErnt mit zweiundVIERzig,
das verdAnk ich meinem MANN,

'Are you a skier then as well,

or...

Yes.

I only learned it at age 42 .

I owe that to my husband.'

(8b) (JE_MB_5.2c)

AUTO VERKAUF $\frac{\mathrm{hn}}{\mathrm{g}-\mathrm{pu}}$

'He sold his car.'

Hence, what we see is that the only illocution type in which the downtoners can occur in an incremental position precisely is the one that normally does not have explicit illocution type markers the kinesic marking could be attracted to. A counterexample seems to be on hand, at first sight, in cases such as (9), in which a headshake immediately following a yes/no-question in DGS to indicate that a negative answer is expected or preferred (similar to the modal particle etwa in German, cf. Section 1.1 above). In this example, the speaker reacts to a friend's proposal to take a shortcut that involves crossing a railway track at a point where there is no grade crossing, and indicates that that is not allowed.

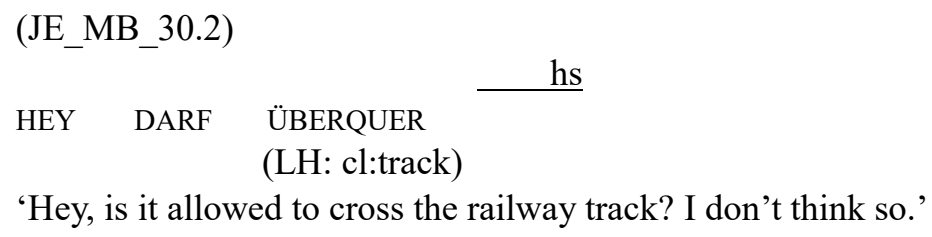

'Hey, is it allowed to cross the railway track? I don't think so.'

However, Pfau (2016: 54) already suggested that the headshake in this case is not actually an increment of the question, but rather constitutes a separate sentence all by itself, without lexical material. This is further supported by the fact 
that this headshake is not accompanied by a palm-up gesture, while incremental downtoners typically are, as in (8b). In a way, the signer himself already answers the question negatively, rather than just suggesting that a negative answer is expected. Hence, we are dealing with a "regular" explicit negation rather than with a purely downtoning headshake, so this use of the headshake does not disprove the observation that incremental downtoning is restricted to assertions.

Once again, there is a correspondence with the topology of modal particles in German: as Imo (2008) and Ormelius-Sandblom (1997) have indicated (among others), modal particles do sometimes occur after the right sentence bracket, i.e. the position for infinite verb forms, rather than in their typical middle field position, as in (10). In this sense, these particles resemble the incremental kinesic downtoning described above in that they follow the normal endpoint of the sentence (the right sentence bracket, i.e. the position for infinite verb forms, cf. Auer 2006).

(10a) Die Autos müssen andersrum fahren. - Ah ja, da hat's gekracht halt. (Imo 2008: 143)

'The cars have to drive the other way. - Oh yeah, that's because there's been a crash.'

(10b) Das kann man verstehen schon. (Ormelius-Sandblom 1997: 33)

'That is understandable.'

Interestingly, this situation has thus far only been described for assertions, and in my data, it also occurs just in this illocution type. ${ }^{3}$ Incremental particles thus seem to occur typically in precisely the sentence type in which kinesic downtoners can be incremental as well, viz. in assertions. In other words, it seems that the topology of both verbal and kinesic downtoners is (partly) determined by the presence or absence of explicit illocution type markers: if there is such a marker (as in $w h$-questions), downtoners are to some extent attracted to it, and the only case in which downtoners can be incremental is when there is no explicit marking of the illocution type.

\footnotetext{
${ }^{3}$ Note that particles in sentence-final position do also occur in other sentence types but are not by definition incremental. In the sentence Was machst $d u$ blo $\beta$ ? 'What the hell are you doing?' the particle $b l o \beta$ is used sentence-finally but still it is in its normal middle field position as it can be said to precede the - empty - right sentence bracket that would be the projected termination point.
} 


\section{Gesture type}

The intricate relation between downtoning and illocution type does not just show in the topology of the downtoners, however. Indeed, a common hypothesis about the German particle denn is that it is actually losing its downtoning function and becoming an illocution type marker for interrogatives (see Thurmair 1989 and Bayer 2012, among others). While this claim is not entirely uncontroversial (cf. Meibauer 1994; and Péteri 2011), the gesture data suggest that there is something to it. The goal of this section is to investigate how the gestures correlating with modal particles in German shed new light on the prominence of the illocution-type-marking function of the latter.

To this end, we have to distinguish two groups of gestures correlating with modal particles. One group consists of the gestures that relate to the downtoning function of the particle and often have a downtoning meaning themselves these are the gestures that were studied above (headshake, nodding, and the like). Apart from these kinesic downtoners, modal particles also recurrently combine with gestures based on the so-called conduit metaphor. Following this metaphor, our utterances are containers or "conduits" and their content is the message we want to convey. Interaction is thus an exchange of such containers. On the basis of this metaphor, a question can for instance be represented gesturally by means of a so-called "palm-up open hand" gesture representing a kind of plate, i.e. the "conduit" the information (the answer) is to be placed upon. The same gesture can also represent an assertion; in this case, the information is presented to the hearer on the plate formed by the hands (see e.g. Kendon 2004; and Müller 2004 for a more elaborate discussion of this presenting use of the "Palm-Up Open Hand"). Other gestures related to assertions are putting a virtual object (the container/message) into the gesture/interaction space and opening a virtual box (the container/conduit) so that its content (the message) becomes accessible. In a way, these gestures can thus be said to metaphorically represent the illocution type (assertion or question).

While these conduit-based illocution-related gestures are certainly not restricted to contexts in which modal particles are used, interesting co-occurrence patterns with these particles can be observed and, next to the downtoning gestures, they are the only gestures co-occurring with modal particles in a systematic way. This takes us to the question of the proportion of these downtoning and illocution-type-related gestures with modal particles. The counts for the six most frequent particles in the data (denn, ja, doch, eben, einfach, and halt) are presented in Table 1. The figures in this table indicate the number of particle at- 


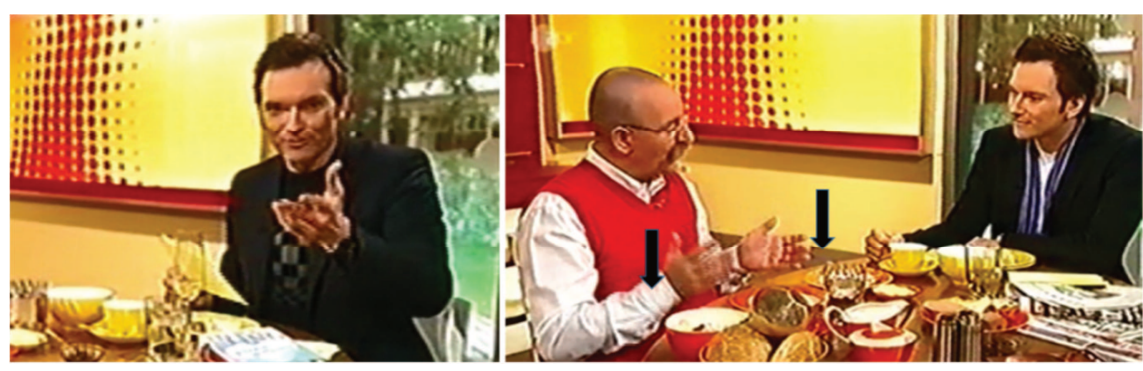

Figure 1. Examples of illocution-type-related gestures:

offering on a plate (left) and putting down in the gesture/interaction space (right).

testations that are accompanied by downtoning gestures (or combinations thereof) only, by illocution-type-related gestures only, and those being accompanied by both a downtoning and an illocution-type-related gesture, respectively.

Table 1. Distribution of the gesture types over the particle attestations.

(The numbers in brackets indicate the absolute frequencies.)

\begin{tabular}{lcccc}
\hline & $\begin{array}{c}\text { downtoning } \\
\text { gesture }\end{array}$ & $\begin{array}{c}\text { + illocution- } \\
\text { type-related } \\
\text { gesture }\end{array}$ & + both & Total \\
\hline denn $(63)$ & $1.59 \%(1)$ & $4.76 \%(3)$ & $4.76 \%(3)$ & $11.11 \%(7)$ \\
ia $(475)$ & $16.00 \%(76)$ & $12.00 \%(57)$ & $9.47 \%(45)$ & $37.47 \%(178)$ \\
doch $(84)$ & $21.43 \%(18)$ & $10.71 \%(9)$ & $5.95 \%(5)$ & $38.10 \%(32)$ \\
halt $(65)$ & $20.00 \%(13)$ & $6.15 \%(4)$ & $10.77 \%(7)$ & $36.92 \%(24)$ \\
eben $(62)$ & $35.48 \%(22)$ & $6.45 \%(4)$ & $3.23 \%(2)$ & $45.16 \%(28)$ \\
einfach $(135)$ & $39.26 \%(53)$ & $3.70 \%(5)$ & $4.44 \%(6)$ & $47.47 \%(64)$ \\
\hline
\end{tabular}

The figures in Table 1 are perhaps not all that telling, given the varying amount of particle attestations not being accompanied by a gesture at all (these were not included in the table). Therefore, Figure 2 presents the same data in the form of a bar plot, so as to make the proportion of downtoning and illocution-typerelated gestures easier to see.

Looking at these data, a striking observation is that there is just one particle for which the illocution-type-related gestures are more frequent than the down- 


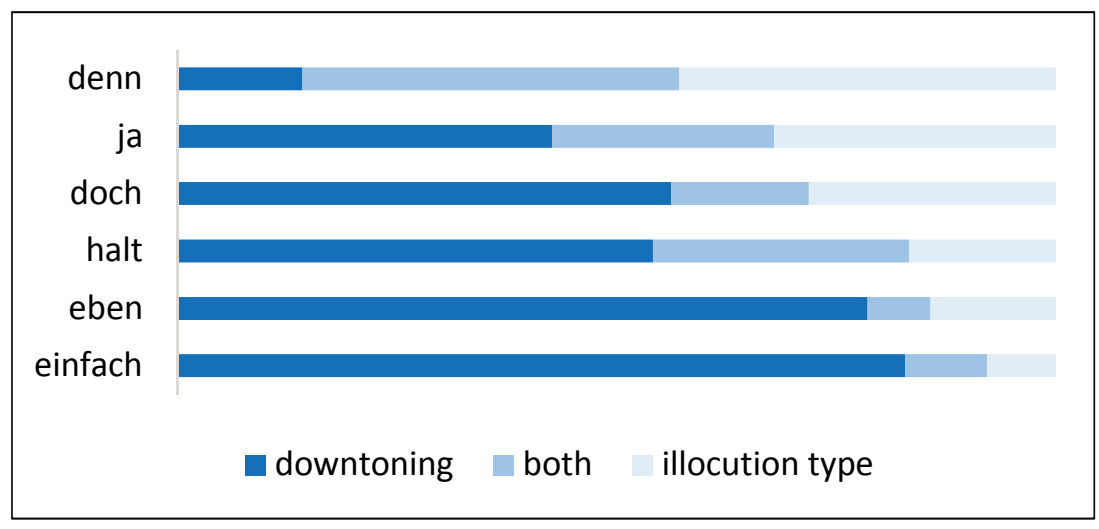

Figure 2. Downtoning and illocution-type-related gestures per particle.

toning gestures, viz. denn. A potential explanation comes from Deppermann (2009), who already indicated that the meaning of denn is rather vague and imprecise. One could even claim that it is more connecting than truly downtoning: As mentioned in section 1, denn indicates that the question follows from some element in the speech situation, typically a preceding turn which is surprising or unexpected, but precisely this nuance of surprise or unexpectedness is not always equally prominent. However, it is not really clear whether this just explains the low amount of downtoning gestures, or rather the low amount of gestures in general, as denn is indeed the particle in Table 1 which most often occurs without accompanying gesture. ${ }^{4}$

The actual explanation for this dominance of illocution-type-related gestures with denn may however still be related to this. If the meaning of denn is so vague and imprecise, this is to a large extent due to its degree of grammaticalization, as indeed, compared to other modal particles, denn is highly grammaticalized (cf. e.g. Schoonjans and Feyaerts 2010), hence subject to a strong desemanticization tendency. The hypothesized evolution of denn towards an interrogative particle would then be a next step in this grammaticalization process:

\footnotetext{
${ }^{4}$ It has to be recalled, however, that the observation that ilocution-type-related gestures are relatively more frequent with denn is based on just seven occurrences of denn with a gesture, so some reticence in generalizing is at order. The observation that denn is more often not accompanied by a gesture at all, on the other hand, is a safer claim to make (compared to eben and halt, which are about equally frequent in the data, the total amount of gestures with denn is significantly lower: $\left.\chi^{2}=29.55 ; \mathrm{p}<0.00001\right)$.
} 
the particle loses its downtoning function entirely and develops into a pure illocution type marker for questions, just like for instance -ne in Latin. The gesture distribution seems to offer further support for this assumption, as indeed the dominant type of gestures with denn is illocution-type-related.

An alternative explanation could be that question marking somehow overrules downtoning. Indeed, denn is not just the only particle in Table 1 that combines more often with illocution-type-related gestures than with downtoning gestures, it is also the only particle in the table that is used in questions, while the others are restricted to assertions and orders (doch can also be used with questions and wishes, but for lack of attestations in the corpus, these uses were not included in the count). As indicated above, assertions present the default illocution type, not needing further marking, so speakers are not restricted in adding downtoning meanings. Questions, on the other hand, are not the default and thus have to be marked explicitly as such, and this would reduce the options for marking downtoning as illocution type marking would be prioritary. However, one could say that downtoning actually also is some kind of illocution type marking, as each downtoner can only be used with particular illocution types (see Section 1.4 above). Furthermore, the data suggest that the hypothesis that question marking overrules downtoning cannot be generalized over other modal particles in questions. Particles such as blo $\beta$ and $n u r$, for instance, which in partial interrogatives indicate that the speaker has no idea of what the answer could be, seem to be combined more often with gestures that convey a similar meaning, such as the headshake discussed in Section 3.1, and not so much with illocution-type-related gestures. These particles are too infrequent in the data to make a firm claim, but for now, I would hypothesize that an overruling of the downtoning by the illocution type marking is not what is happening here.

\section{Conclusion and outlook}

In this paper, I have tried to show that the analysis of the gestures co-occurring with modal particles in German and the corresponding downtoning patterns in DGS offers a new perspective on the relation between downtoning and illocution type. While the discussion whether downtoners simply indicate or also modify the illocution type could not be resolved, a closer look at the topology of verbal and kinesic downtoners and an analysis of the types of gestures used with modal particles illustrate how this link between downtoning and illocution type shows in the use of downtoners. 
With regard to topology, previous research had shown that this is influenced, among other things, by information-structural parameters such as focus (e.g. Moroni 2010), but the present study suggests that the presence or absence of explicit illocution type markers plays a role as well, ${ }^{5}$ in that there seems to be a kind of attraction between downtoners and explicit illocution type markers such as question words, allowing modal particles for instance to leave their canonical middle field position to appear adjacent to this other marker, while assertions, being the only illocution type that is not in need of explicit marking, also present the only illocution type in which downtoners can occur in an incremental position. Concerning the gesture types related to modal particles, on the other hand, the data offer further support for the idea that the particle denn is losing its status as a downtoner and becoming a question particle, as indeed it is the only particle which is accompanied more often by an illocution-type-related gesture than by a real downtoning gesture.

At the same time, however, some points are still in need of further investigation. Concerning the last point (more illocution-type-related gestures with denn as it is becoming a question particle), for instance, it has been indicated in Section 4 that the observations concerning particles such as nur and blo $\beta$ are still hypothetical. As for the observations on DGS in Section 3, on the other hand, it would be interesting to check if and to what extent there is interference with non-manual illocution type marking, such as the brow raise for questions. Apart from that, it would also be interesting to see to what extent the observations made for modal particles also hold for other verbal downtoners in German, such as the so-called IAW structures, i.e. forms such as in aller Welt 'in all world' used as a kind of intensifiers in $w h$-questions and indicating "incomprehension of the speaker with regard to the sentence's proposition" (Stefanowitsch 2011: 190; my translation). A further question in this respect would be why, in the case of particle combinations, sometimes only one particle is attracted towards the illocution type marker, as in (11). Interestingly, it is not necessarily the particle denn that is attracted, as shown in (11) and unlike what one could

\footnotetext{
${ }^{5}$ An anonymous reviewer raises the question to what extent these two parameters (focusdependency and illocution-type-marking-dependency) are interrelated, as for instance question words are often focused. To answer this question, one would have to compare the downtoners's behavior in cases where the question word is in focus with cases where it is not, but this goes beyond the scope of the present paper. However, it is not clear how this would explain (among other things) the attraction between downtoners and (in)subordinators suggested in Section 3.2, as (in)subordinators are less often focused. Hence, while an interrelation of focus-depencency and illocution-type-marking dependency cannot be excluded, further research is needed to clarify the issue.
} 
perhaps expect as it is the one which has a stronger illocution-type-marking function. On the other hand, precisely that might explain the phenomenon, in the sense that the attraction we observe is between downtoning and illocutiontype-marking, explaining that it is the particle with the stronger downtoning function that is attracted towards the question word, while denn, being "just" a non-propositional particle, is not strong enough to exert such an attraction. More research is definitely needed here to answer this question.

Warum nur musste ich denn zurück? (COSMAS-II)

'But why, o why did I have to go back?'

Hence, there still is a lot of work to do, but still the data suggest that the link between downtoning and illocution type is reflected in how the downtoners are used.

\section{Acknowledgements}

I would like to thank Wolfgang Imo and Jens Lanwer for discussing some of the issues raised in this paper, and three anonymous reviewers for their valuable feedback on an earlier version of the paper.

\section{References}

Abraham, W. 2010. "Diskurspartikel zwischen Modalität, Modus und Fremdbewusstseinsabgleich". In: Harden, T. and E. Hentschel (eds.), 40 Jahre Partikelforschung. Tübingen: Stauffenburg. 33-78.

Auer, P. 2006. "Increments and more. Anmerkungen zur augenblicklichen Diskussion über die Erweiterbarkeit von Turnkonstruktionseinheiten”. In: Deppermann, A., R. Fiehler and T. Spranz-Fogasy (eds.), Grammatik und Interaktion. Radolfzell: Verlag für Gesprächsforschung. 279-294.

Autenrieth, T. 2002. Heterosemie und Grammatikalisierung bei Modalpartikeln. Tübingen: Niemeyer.

Bayer, J. 2012. "From modal particle to interrogative marker: A study of German denn". In: Brugé, L. et al. (eds.), Functional heads. Oxford: Oxford University Press. 1328.

Bayer, J. and A. Trotzke. 2015. "The derivation and interpretation of left peripheral discourse particles". In: Bayer, J. et al. (eds.), Discourse-oriented syntax. Amsterdam: Benjamins. 13-40. 
Brandt, M., M. Reis, I. Rosengren and I. Zimmermann. 1992. "Satztyp, Satzmodus und Illokution”. In: Rosengren, I. (ed.), Satz und Illokution. (Band 1.) Tübingen: Niemeyer. 1-90.

Bressem, J. and C. Müller. 2014. "The family of Away gestures: Negation, refusal, and negative assessment”. In: Müller, C. et al. (eds.), Body-language-communication (vol. 2). Berlin: De Gruyter. 1592-1604.

Debras, C. \& A. Cienki. 2012. "Some uses of head tilts and shoulder shrugs during human interaction, and their relation to stancetaking". In: [s.n.] (ed.), Proceedings of the 2012 ASE/IEEE International Conference on Social Computing and 2012 ASE/IEEE International Conference on Privacy, Security, Risk and Trust. 932-937. $<\mathrm{http}$ ://ieeexplore.iee.org/stamp/stamp.jsp?tp=\&arnumber=6406348>, last accessed on 9 June 2017.

Deppermann, A. 2009. "Verstehensdefizit als Antwortverpflichtung: Interaktionale Eigenschaften der Modalpartikel denn in Fragen”. In: Günthner, S. \& J. Bücker (eds.), Grammatik im Gespräch: Konstruktionen der Selbst- und Fremdpositionierung. Berlin: de Gruyter. 23-56.

Heinrichs, W. 1981. Die Modalpartikeln im Deutschen und Schwedischen. Tübingen: Niemeyer.

Herrmann, A. 2007. "The expression of modal meaning in German Sign Language and Irish Sign Language”. In: Perniss, P., R. Pfau and M. Steinbach (eds.), Visible variation: Comparative studies on sign language structure. Berlin: de Gruyter. 245278.

Herrmann, A. 2013. Modal and focus particles in sign languages. Boston: De Gruyter. Imo, W. 2008. "Individuelle Konstrukte oder Vorboten einer neuen Konstruktion? Stellungsvarianten der Modalpartikel halt im Vor- und Nachfeld”. In: Stefanowitsch, A. and K. Fischer (eds.), Konstruktionsgrammatik II: Von der Konstruktion zur Grammatik. Tübingen: Stauffenburg. 135-155.

Kendon, A. 2002. "Some uses of the head shake". Gesture 2. 147-182.

Kendon, A. 2004. Gesture: Visible action as utterance. Cambridge: CUP.

Mangelschots, K. and S. Schoonjans. 2017. "Multimodale Evidentheitsmarkierung im Deutschen." Linguistik Online 81. 95-125.

Meibauer, J. 1994. Modaler Kontrast und konzeptuelle Verschiebung. Tübingen: Niemeyer.

Moroni, M. 2010. Modalpartikeln zwischen Syntax, Prosodie und Informationsstruktur. Frankfurt/Main: Lang.

Müller, C. 2004. "Forms and uses of the Palm Up Open Hand: A case of a gesture family?" In: Müller, C. and R. Posner (eds.), The semantics and pragmatics of everyday gestures. Berlin: Weidler. 233-256.

Müller, S. 2014. Modalpartikeln. Heidelberg: Winter.

Ormelius-Sandblom, E. 1997. Die Modalpartikeln ja, doch und schon. Stockholm: Almqvist \& Wiksell.

Péteri, A. 2011. "Interrogativpartikeln und Modalpartikeln. Ihre Abgrenzung in ausgewählten europäischen Sprachen”. Germanistische Studien 8. 93-107.

Pfau, R. 2016. "A featural approach to sign language negation”. In: Larrivée, P. and C. Lee (eds.), Negation and polarity: Experimental perspectives. Cham: Springer. 4574. 
Rinas, K. 2007. "Bekanntheit? Begründung? Einigkeit? Zur semantischen Analyse der Abtönungspartikel ja". Deutsch als Fremdsprache 44(4). 205-211.

Schoonjans, S. 2014. Modalpartikeln als multimodale Konstruktionen. (PhD dissertation, KU Leuven.)

Schoonjans, S. 2015. “Topologie contrastive des particules de démodulation”. In: Lavric, E. and W. Pöckl (eds.), Comparatio delectat II. Frankfurt/Main: Lang. 417-431.

Schoonjans, S. 2016. "Neue Gedanken zum topologischen Satzmodell des Deutschen". Leuvense Bijdragen 99-100. 64-86.

Schoonjans, S. and K. Feyaerts. 2010. "Die Übersetzung von Modalpartikeln als Indiz ihres Grammatikalisierungsgrades: die französischen Pendants von denn und eigentlich". Linguistik Online 44. 67-85.

Selting, M., et al. 2009. "Gesprächsanalytisches Transkriptionssystem 2 (GAT2)". Gesprächsforschung 10. 353-402.

Stefanowitsch, A. 2011. "Keine Grammatik ohne Konstruktionen: Ein logischökonomisches Argument für die Konstruktionsgrammatik". In: Engelberg, S., A. Holler and K. Proost (eds.), Sprachliches Wissen zwischen Lexikon und Grammatik. Berlin: de Gruyter. 181-210.

Thurmair, M. 1989. Modalpartikeln und ihre Kombinationen. Tübingen: Niemeyer.

Thurmair, M. 1993. "Äußerungsform oder Äußerungsfunktion? Zu den Bedingungen für das Auftreten von Modalpartikeln”. Deutsche Sprache 21(1). 22-43.

Trotzke, A. \& G. Turco. 2015. "The grammatical reflexes of emphasis: Evidence from German wh-questions". Lingua 168. 37-56.

Waltereit, R. 2006. Abtönung. Zur Pragmatik und historischen Semantik von Modalpartikeln und ihren funktionalen Äquivalenten in romanischen Sprachen. Tübingen: Niemeyer.

Whitehead, K. "Some uses of head nods in 'third position' in talk-in-interaction". Gesture 11. 103-122.

\section{Address for correspondence:}

Steven Schoonjans

Institut für Germanistik

Universität Innsbruck

Innrain 52d

6020 Innsbruck

Austria 